\title{
Working Capital Management in Indonesia: An Analysis on Overinvestment and Underinvestment Firms
}

\author{
Rabmat Heru Setianto ${ }^{1 *}$ and Adinda Pratiwi ${ }^{2}$ \\ ${ }^{1}$ Faculty of Economics and Business, Universitas Airlangga, Surabaya, Indonesia \\ ${ }^{2}$ PT Schneider Electric Indonesia, Jakarta, Indonesia
}

\begin{abstract}
This study aims to examine the existence of excess working capital in Indonesian firms and its effect on the firms' performance and risk. The sample includes 425 firm-year observations of Indonesian manufacturing firms for the period 2010 - 2014. To account for the potential asymmetric relation between excess Net Working Capital (NWC) and firm performance, an asymmetric regression model is employed, allowing the slope coefficient of the excess NWC to be different for positive and negative excess NWC. The results indicate (i) the existence of an optimal level of working capital, (ii) higher excess working capital leads to lower performance and risk, (iii) additional investment in working capital reduces firms' performance for those with positive excess working capital. It is also documented that (iv) additional investment in working capital reduces firms' risk for those that have working capital deficiencies. The findings have important implications for corporate managers in determining the optimal level of working capital.
\end{abstract}

Keywords: excess working capital; performance; risk; working capital management JEL classification: G31, G32 


\section{Introduction}

Working Capital Management (WCM), along with investment and financing decisions, is essential for financial managers who have the goal of maximizing their company's value. With efficient working capital management, a firm can allocate its capital to more strategic goals that are able to enhance the firm's performance (Lind et al. 2012). According to Smith (1980), working capital management plays an important role in profitability, firm risk and corporate values. If a firm fails to manage its working capital, it will struggle to maximize its corporate values, due to poor shortterm asset and liability management. Working capital management is considered as optimum if the amount of working capital available matches the optimal amount required, not exceeding (overinvestment) nor falling below (underinvestment) what is needed. The basic question with working capital management is "What is the optimal amount of working capital that should be invested to maximize firm performance?"

According to Ernst and Young's analysis report on working capital (2015), a high level comparative analysis of 2,000 US and Europe companies indicated that there is an excess of working capital, by US\$ 1.3 trillion above the optimal level to operate businesses efficiently and meet their operating requirements. This amount is equivalent to 7 percent of their total sales, which means that for every US\$ 1 billion of sales, the opportunity for an increase in working capital is US\$ 70 million. Buchmann et al. (2008) argue that the ability of net working capital, as a potential source of funds to support firm growth, is often ignored by most companies. Com- panies can allocate their excess working capital for business expansion, so that they will not need to search for external sources of funding.

Previous studies on the relationship between working capital and firm performance, conducted in developed and developing countries with various model approaches and measurements, fall into two competing views of working capital's investment. Shin and Soenen (1998) and Deloof (2003) disclose a positive relationship between the net working capital and corporate profitability, in which higher working capital will encourage companies to increase sales and enjoy bigger sales discounts for early payment. Meanwhile, Kieschnick et al. (2013) reveal an opposite result for companies in the US, in which each additional investment in working capital, on average, will reduce excess stock returns. The greater the amount of investment required for the working capital, the greater the firm's financing expenses.

By taking into account the different effects of working capital on firm performance, this study identifies the sources of the differences by observing the level of working capital invested by each firm, whether it had reached the optimal level or not. Studies conducted by Faulkender and Wang (2006) and Wang (2002) also support the view that reducing working capital will actually increase firms' values. Some studies have also adopted nonlinear models to examine the nonlinearity potentials between working capital and corporate values, as conducted by Banos-Caballeroet al. (2012) on Spanish firms and Banos-Caballero et al. (2014) on UK firms. They documented an inverted U-shaped relationship between NWC and stock performance. Accordingly, comparable evidence in a de- 
veloping market (i.e. Indonesia) is provided, and these studies are extended by emphasizing the effects of WCM on firm risk.

In the context of Indonesia, a study evaluating the effects of WCM on corporate profitability was conducted by Charitou et al. (2012) who investigated the impact of WCM as measured by the Cash Conversion Cycle (CCC) and Net Trade Cycle on profitability after the global financial crisis. It revealed a positive effect of working capital investment on profitability, proxied by the ROA (Return on Assets). The study also proves that the level of firm risk calculated with a debt ratio has a negative relationship with ROA. Related to the issue of the global financial crisis, Rozari et al. (2015) examined various effects of working capital's efficiency on financial performance in Indonesia during the crisis. Measurements were made using CCC and working capital policies (investment and financing) on profitability, as measured by ROA, and the market value as calculated by Tobin's Q. The results of this study indicate that CCC (and its components) and working capital policies have different impacts on corporate profitability during the period of crisis, as compared to other periods. Moreover, the study also shows that there is no difference between the effects of CCC (and its components) and working capital policy on corporate values within the similar periods being compared. Hence, this study indicates that the global financial crisis tended to encourage companies to change their working capital policies, in order to become more efficient.

Indonesia provides an interesting case study, as empirical studies were very rarely carried out in developing countries, including Indonesia. Indonesia has the characteristics of an emerging market, with high eco- nomic growth over the past decade, along with the other three countries with the highest economic growth, namely China, India and Brazil. These conditions provide incentives to firms in Indonesia to grow more rapidly and to influence their shortterm and long-term investment policies. In addition, most of the firms in an emerging economy are small in size and have limited access to funding from the capital markets. Hence, firms in developing countries tend to use self-financing, trade credit and shortterm bank loans to pay for investment in receivables and inventory (Chittenden et al. 1998).

In the light of the facts above, this paper attempts to extend the previous studies into working capital management in an emerging economy in several novel ways. Studies on working capital's management in Indonesia have been more focused on observing the linear relationship between the level of working capital and firm performance, as seen from the measuring instrument used, namely the value of the cash conversion cycle and the proportion of current assets. Theoretically, a working capital policy should have a nonlinear relationship with firm performance, which signifies a trade-off between a working capital policy that is too aggressive and one that is too conservative. The nonlinear relationship has not yet been accommodated in the existing research. More specifically, this study seeks to contribute to the studies related to working capital's management in at least three areas: (1) excess working capital is employed to measure working capital management, namely the difference between the actual working capital and the optimal working capital, in order to examine the existence of overinvestment in the practice of working capital management in 
Indonesia, which normally occurs in developed economies; (2) to investigate to what extent additional working capital affected performance, more specifically in both underinvestment and overinvestment companies; (3) besides performance, an aggressive working capital policy also relates to the level of risk, namely the risk of fluctuations in supply costs and the loss of sales due to stock-outs. Therefore, the study examines the effect of working capital policy on risk, and also observes the asymmetric effect of the addition to working capital on risk, in both overinvestment and underinvestment firms.

The body of the paper is organized as follows: The following section discusses the relevant literature on working capital's value and risk relationship. Section 3 describes the data used in the empirical analysis and the models to be employed. Section 4 reports the empirical results of the relationship between improvements in working capital management and firm performance and risk; and Section 5 concludes the study.

\section{Working Capital, Firm Value, and Risk}

Working capital management is important because of its effects on a firm's profitability and risk, and consequently its value (Smith 1980). The importance of working capital can also be seen from its significant proportion to total assets, and the high use of trade credits as a source of funds for firms. Cunat (2007) finds that 41 percent of total debt is accounted from trade credits. Emery (1984) even argues that trade credits are more profitable than marketable securities, in terms of short-term investment for firms. Fazzari and Petersen
(1993) also agree that working capital acts as a liquidity buffer if the company suddenly falls short of cash.

Numerous studies have empirically investigated the working capital and value relationship for various countries. They fall into two competing views of working capital's policies. Under one view, higher working capital may increase firms' value. Some studies supporting this view include Moussa (2018), Wasiuzzaman (2015), Abuzayed (2012), Mohamed and Saad (2010), Ogundipe et al. (2012), Deloof (2003), Lee and Stowe (1993), Blinder and Maccini (1991), and Dunn and Cheatham (1993) who found a positive relationship between working capital and firm value. Alternatively Almeida and Eid (2014), Vural et al. (2012), Kieschnick et al., (2011); Garcia-Teruel and Martinez-Solano (2007), and Deloof (2003) report a negative association between working capital and value.

Theoretically, there are some possible explanations regarding companies' motives to invest a large amount of working capital. According to Blinder and Mancini (1991), the greater the quantity of supplies they hold, the less their supply costs are. Thus, companies will negate the risk of higher prices set by their suppliers, and they will also prevent disruption to the production process, and the loss of sales, due to product shortages. The large stock of supplies also enables the firms to provide better services to their consumers and reduces the possibility of stock-outs. In addition, a credit sales policy, in the long term, will increase sales and customer loyalty (Petersen and Rajan 1997; Ng et al. 1999; Wilner 2000). The increase in sales and customers' loyalty, from consumers' perspectives, will provide benefits includ- 
ing allowing buyers to verify the quality of the goods before making payment, so it will lessen the asymmetric information between buyers and sellers (Lee and Stowe 1993; Smith 1987). Moreover, Deloof and Jegers (1996) state that a credit sales facility would be a consideration for consumers in choosing products, when the quality of the existing products on the market is similar. Credit sales will also encourage consumers to make purchases when demand is low (Emery 1987). From the perspective of shortterm investment, investments in receivables provide greater benefits than investments in marketable securities (Emery 1984).

On the other hand, excessive investment in working capital is likely to have a negative impact on firm performance. The great number of inventory items would increase the inventory costs, entailing increased warehouse rental fees, insurance and security costs (Kim and Chung 1990). In addition, a large amount of working capital will require substantial trade credits, which will increase the financing costs, including interest expenses, thus putting the company at greater risk of financial distress (Kieschnick et al. 2013). Moreover, substantial investment in working capital will lock funds in the working capital, which eventually will reduce a firm's ability to execute unexpected profitable investment opportunities (Deloof 2003). Therefore, a decrease in the amount of excessive net working capital (over and above the optimal amount of working capital) can increase a firm's financial flexibility in the short term and, in the long term, it can reduce the need for funding to finance the activities of the firm's daily operations. Furthermore, firms with financial flexibility have a greater ability to take a variety of investment oppor- tunities (Denis and Sibilkov 2010; Duchin et al. 2010). On the other hand, aggressively employed working capital utilizes a low level of working capital, although lowering the cost of capital will increase the risk of liquidity as well as shortages.

There is an extensive debate on the risk and return trade-off between different working capital policies. The most accepted one says that more aggressive working capital policies are linked to higher returns and higher risk, while conservative working capital policies are concerned with lower risk and returns. The greater the investment in current assets, the lower the risk; but also the lower the profitability obtained. BanosCaballero et al (2013) and Aktas et al. (2015) state that there is a trade-off in working capital decisions, so firms should have an optimal working capital level that will balance the benefits and costs from holding a certain amount of working capital, and maximize their value. More specifically it is expected that the performance and value of the firm rise as working capital increases until a certain level is reached. Conversely, beyond the optimal level, the working capital and value relationship will be negative.

Moreover, firm risk is a possible explanation channel through which working capital policies translate into market performance. A firm with highly aggressive working capital management might increase its risk, among others, because of uncertainty about its supply costs, and loss of sales due to potential stock-outs (Blinder and Maccini (1991); Fazzari and Peterson (1993) and Corsten and Gruen (2004). Therefore, the negative impact of working capital on a firm's value might be due to increasing firm risk following a decrease in the level of working capital. 
Based on the above discussion, the following hypotheses are posited:

Hypothesis 1. Overinvestment in net working capital has a negative effect toward firm performance.

Hypothesis 2. In overinvestment companies, an addition to the working capital has a negative effect toward firm performance and vice versa.

Hypothesis 3. Overinvestment in net working capital has a negative effect toward firm risks.

Hypothesis 4. In underivestment companies, an addition to the working capital has a negative effect toward firm risks and vice versa.

\section{Methods}

\section{Sample Construction}

The study employs data from manufacturing firms that have been listed on the Indonesian stock exchange during the period from 2005 to 2014 . The sample is chosen in accordance with Hill et al. (2010), who stated that the working capital policies of manufacturing companies are clearly different from those of service companies, since the manufacturing sectors normally have high inventory levels while the service sectors generally have no inventories at all. Thus, to avoid bias due to differences in the business characteristics of the different industries, this study used manufacturing firms as its samples. Data were obtained from the financial statements provided by the Indonesian Stock Exchange's website. Sampling was conducted by using the purposive sampling method with the following criteria: a) com- panies are listed on the stock exchange from 2005-2014 and categorized as manufacturing companies; b) the companies' financial statements present the complete financial data necessary for calculating the variables; c) there is no negative equity; and d) the financial statements are presented in rupiah.

\section{Variable Definition and Empirical Method}

\section{Dependent Variables}

In this study, firm performance is measured by each firm's abnormal returns. According to Barber and Lyon (1997), the calculation of a firm's abnormal returns should be carried out by subtracting the buy-and-hold returns on the reference portfolio from the firm's buy-and-hold returns. Furthermore, their study reveals that the use of an equally weighted market index, or decile portfolios based on firm size, is not entirely accurate for calculating the long-term abnormal returns. In Indonesia, the frequently used market index portfolio (market index) is the Jakarta Composite Index (JCI) portfolio. In general, according to Barber and Lyon (1997), there are three reasons why the calculation is inaccurate: (1) bias of the new listing companies, due to the fact that the market index (reference portfolio) combines companies that have been listed for a long time with new listing companies; (2) rebalancing bias, which generally occurs as the compound return of the reference portfolio, such as a market index (in Indonesia, JCI), rebalances in a certain period (usually monthly), while the calculation of the firms' compound returns do not do so; (3) skewness bias, which arises as the accumulation of long-term abnormal returns has a positive skew. 
Accordingly, following Barber and Lyon's approach (1997), this research used BHAR (Buy-and-Hold Abnormal Returns) to calculate the excess return, by subtracting the return of the buy-and-hold reference portfolio from the return of the buyand-hold sample companies, using the calculation shown Equation 1.

Excess return $_{i, t}=\prod_{m}^{T}{ }_{1}\left(1+R_{i, m}\right) \quad \prod_{m}^{T}{ }_{1}\left(1+R_{i, p}\right)$

$R_{i, m}$ is firm return $\mathrm{i}$ and $R_{i, p}$ is the corresponding return for the benchmark portfolio for month $\mathrm{m}$, and $\mathrm{T}$ is the horizon in number of months. Excess returns over the one-year horizon $(T=12)$ were computed. According to Fama and French (1993), the benchmark portfolios are the ten portfolios constructed by independently sorting stocks based on their size (market value of common equity) and grouped into ten deciles.

Furthermore, according to Aktas et al. (2014), companies that implement too aggressive a working capital policy can have a high level of firm risk. This is caused by the fluctuations in supply costs, and the loss of sales due to stock-outs. Therefore, his research assumes that the negative relationship between positive excess NWC and the firm's stock performance may be affected by the increase in firm risk due to reducing the amount of NWC. In this study, firm risk was calculated with an annual standard deviation from the companies' monthly returns.

$$
S_{X}=\sqrt{\frac{1}{12 \quad 1} \sum_{i}^{12}\left(x_{i} \quad \bar{x}\right)^{2}}
$$

$\mathrm{S}$ is the standard deviation, $x_{\overline{\mathrm{I}}}$ is a firm's stock return in month $\mathrm{i}$, and $\bar{x}$ is the average stock returns of firm $\mathrm{x}$ for 12 months. The larger the standard deviation, the greater the firm risk.

\section{Independent Variable}

The concept of working capital was originally intended to ensure that a firm could meet its liabilities. Holding a sufficient quantity of working capital would guarantee that the firm would be able to meet its short term obligations. Thus, the main objective of working capital management in business management is to ensure that short-term assets will be in accordance with the short-term liabilities. However, Fess (1966) states that Working Capital Management (WCM) is now no longer seen in this way, in an enterprise whose primary role is to maintain the level of liquidity in sufficient quantity during the liquidation of a firm. According to Faden (2014), since the mid-20th century, the firms' focus has shifted to their going-concern value;. while the new paradigm of the WCM is to optimize a firm's operating cycle and simultaneously maximize the corporate profitability.

Traditional liquidity ratios, namely the current ratio, the quick ratio and net working capital, aim to serve as a liquidity indicator by matching current assets to current liabilities. In fact, according to Faden (2014) from the going-concern perspective, in addition to observing whether current assets can cover short term liabilities, the observer may also be interested in distinguishing the changes to the operating cycle, and the changes due to the firm's financial strategies. According to Shulman et al. (1985), the ratios disregard the effect of 
changes in the operating cycle on the firm liquidity, and the effect of changes in the amount of capital on the operating cycle. For example, a firm can increase its cash reserves related to its investment plans and, therefore, significant changes will appear in the liquidity ratios. As a result, external observers will not be able to identify whether the increase in the liquidity is a result of the changes in the operating cycles or the financial strategies.

Correspondingly, Shulman et al. (1985), then defines Net Working Capital (NWC) as two separate components, namely the Working Capital Requirement (WCR) and the Net Liquid Balance (NLB). The WCR represents the operating cycle, while the NWC represents liquidity accounts. Therefore, in this study, working capital is defined as a working capital requirement, namely the number of receivables and inventories.
Furthermore, according to Hill et al. (2010), each firm will require different levels of working capital, depending on the characteristics of the industry. Thus, as a control over the characteristics of the industry, the industry-median adjusted NWC to sales ratio was used as the main variable of interest. The calculation of the NWC is as Equation 3.

$\mathrm{NWC}=\mathrm{AR}+\mathrm{INV}-\mathrm{AP}$

$\mathrm{AR}$ is accounts receivable; INV is inventory; and AP is accounts payable. The calculation of the ratio of NWC-to-sales was then carried out by dividing the NWC by the total sales during the year. Excess NWC is calculated by subtracting the NWC-tosales ratio of a given firm from the median ratio NWC-to-sales in the corresponding industry/years. The median value serves as the proxy for the optimum amount of NWC.

\section{Tabel 1.Variable Definitions}

\begin{tabular}{|c|c|}
\hline Variables & Definition \\
\hline Excess return & $\begin{array}{l}\text { The difference between the buy-and-hold investment return in sample } \\
\text { companies and the one in the benchmark portfolio. The equation is as } \\
\text { follows: }\end{array}$ \\
\hline & Excess return $_{i, t}=\prod_{m 1}^{T}\left(1+R_{i, m}\right) \quad \prod_{m 1}^{T}\left(1+R_{i, p}\right)$ \\
\hline Risk & Standard deviation of monthly stock return \\
\hline Excess NWC & $\begin{array}{l}\text { NWC to sales ratio minus the industry median of the NWC-to-sales } \\
\text { ratio in the corresponding year. }\end{array}$ \\
\hline Firm Size & Natural logarithm of market capitalization \\
\hline Leverage & Total debt scaled by total assets \\
\hline Age & Number of years since first trading date in the natural logarithm \\
\hline Cash reserve & Cash and equivalents to total assets \\
\hline Sales volatility & $\begin{array}{l}\text { The standard deviation of firm's annual sales over the previous five- } \\
\text { year period }\end{array}$ \\
\hline Cash flow & Operating cash flow to total assets \\
\hline Sales growth & Percentage change in sales \\
\hline
\end{tabular}


Excess NWC shows the amount of cash that is not required in a firm's working capital. If the result is positive, then the firm will invest the excess cash in working capital. If negative, the firm will adopt a very aggressive working capital policy. A more detailed explanation regarding the operational definition of the control variables is shown in Table 1.

\section{Model Specifications}

Following Aktas et al. (2015) the impact of excess NWC on firm performance was examined by employing the following linear regression model (Equation 4):

1-year excess return ${ }_{i, t}=$

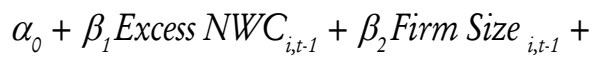

$$
\begin{aligned}
& \beta_{3} \text { Leverage }_{i, t-1}+\beta_{4} \text { Age }_{i, t-1}+\beta_{5} \text { Risk }_{i, t-1}+ \\
& \beta_{6} \text { Fixed Assets } \text { Growth }_{i, t-1}+ \\
& \beta_{7} \text { Cash Reserves }_{i, t-1}+\beta_{8} \text { Sales Volatility }_{i,-1}+ \\
& \beta_{9} \text { Cash Flow }_{i,-1}+\beta_{10} \text { Sales Growth }_{i, t-1}+ \\
& \varepsilon_{i t .1}
\end{aligned}
$$

To account for the potential asymmetric relationship between excess NWC and firm performance, the asymmetric regression model was employed allowing the slope coefficient of the excess NWC to be different for positive and negative excess NWC. The considered asymmetric model specification is as Equation 5.

1-year excess return ${ }_{i, t}=$

$$
\begin{aligned}
& \alpha_{0}+\gamma_{1}[\operatorname{Excess} N W C \mathrm{x}(1-D)]+ \\
& \gamma_{2}\left[\operatorname{Excess}_{N} N C_{i, t-1} \mathrm{x}(1-D)\right]+ \\
& \gamma_{3} \text { Firm Size }_{i, t-1}+\gamma_{4} \text { Leverage }_{i, t-1}+\gamma_{5} \text { Age }_{i, t-1}+ \\
& \gamma_{6} \text { Risk }_{i, t-1}+\gamma_{7} \text { Fixed Assets Growth }{ }_{i, t-1}+ \\
& \gamma_{8} \text { Cash Reserves }_{i, t-1}+\gamma_{9} \text { Sales Volatility }_{i, t-1}+ \\
& \gamma_{10} \text { Cash Flow }_{i, t-1}+\gamma_{11} \text { Sales Growth }_{i, t-1}+ \\
& \varepsilon_{i, t .1}
\end{aligned}
$$

$\mathrm{D}$ is a dummy variable that equals one if the corresponding excess NWC is positive, and zero (0) if otherwise.

Furthermore, Aktas et al. (2015) states that firm risk is a plausible alternative for the increase in stock performance following the decrease in working capital. Companies that adopt aggressive working capital policies are highly likely to increase the risks, such as fluctuations in their stock processes and loss of sales due to potential stock-outs. To examine the impact of excess NWC on risk, the following regression specification (Equation 6) was used.

$$
\begin{aligned}
\text { Risk }_{i, t}= & \alpha_{0}+\beta_{1} \text { Excess NWC }_{i, t-1}+\beta_{2} \text { Firm Size }_{i, t-1}+ \\
& \beta_{3} \text { Leverage }_{i, t-1}+\beta_{4} \text { Age }_{i,-1}+ \\
& \beta_{5} \text { Cash Reserves }_{i, t-1}+\beta_{6} \text { Sales Volatility }_{i,-1-1}+ \\
& \beta_{7} \text { Cash Flow }_{i, t-1}+\beta_{8} \text { Sales Growth }_{i, t-1}+\varepsilon_{i, t-1}
\end{aligned}
$$

As in the previous model, the potential of a nonlinear relationship between excess working capital and risk was also investigated. For this purpose, the following model was used (Equation 7).

$$
\begin{aligned}
\text { Risk }_{i, t}= & \alpha_{0}+\gamma_{1}[\text { Excess NWC }(1-D)]+ \\
& \gamma_{2}\left[\text { Excess NWC }_{i, t-1} \mathrm{x}(1-D)\right]+ \\
& \gamma_{3} \text { Firm Size }_{i,-1}+\gamma_{4} \text { Leverage }_{i, t-1}+\gamma_{5} \text { Age }_{i, t-1}+ \\
& \gamma_{6} \text { Cash Reserves }_{i, t-1}+\gamma_{7} \text { Sales Volatility }_{i,-1-1}+ \\
& \gamma_{8} \text { Cash Flow }_{i, t-1}+\gamma_{9} \text { Sales Growth }_{i,-1}+\varepsilon_{i, t-1}
\end{aligned}
$$

The proxy used for corporate risk is the annualized standard deviation of monthly stock return, where $\mathrm{D}$ is the dummy variable that equals one if the corresponding excess NWC is positive, and zero ( 0 ) if otherwise. All of the independent variables are lagged by one year, with respect to the dependent variables. 
To account for the potential endogenity problem that might arise because of the observed relationships between the dependent variables and the firmspecific characteristics, as the independent variables, which reflect not only the effect of the independent variables on the dependent variables, but also the effect of the dependent variables on the independent variables. We therefore estimated our models using the Generalized Method of Moments (GMM) estimator, developed by Arellano and Bond (1991). More specifically we used right-hand side variables in the models as instruments in the difference equations.

\section{Results and Analysis}

\section{Descritpive Statistics}

Tables 2 and 3 present the descriptive statistics and the distribution of samples in each industry sector. The average value of the excess NWC variable in Table 1 shows a positive value, indicating that most of the sample companies experienced an overinvestment in their working capital.

Table 2 shows the distribution of the median value of net working capital to the sales ratio. Median values presented in Table 3 indicate the heterogeneity of the NWC policy in each industry sector in the group of manufacturing companies (basic industry and chemicals, miscellaneous industries, and consumer goods industries). The table shows that each of the three groups of the largest industry sub-sectors consists of nine companies (metal and allied products, automotive and components, and food and beverages) and each of the three groups of the smallest industry subsectors consists of two companies (wood industries, footwear, and houseware). Table 3 also presents the estimated coefficient of the time trend (slope) variable, and

Table 2. Descriptive Statistics $(\mathbf{n}=\mathbf{4 2 5})$

\begin{tabular}{lrrrr}
\hline \multicolumn{1}{c}{ Variables } & Minimum & Maximum & \multicolumn{1}{c}{ Mean } & \multicolumn{1}{c}{ Std. Dev. } \\
\hline Excess return & -2.881 & 2.733 & -0.097 & 0.540 \\
Risk & 0.000 & 1.012 & 0.124 & 0.100 \\
Excess NWC (all) & -0.392 & 0.482 & 0.009 & 0.147 \\
Excess NWC (+) & 0.000 & 0.482 & 0.059 & 0.097 \\
Excess NWC (-) & -0.392 & 0.000 & -0.049 & 0.081 \\
Firm Size & 8.900 & 14.441 & 11.812 & 1.022 \\
Leverage & 0.043 & 3.212 & 0.520 & 0.399 \\
Age & 0.581 & 1.513 & 1.247 & 0.127 \\
Fixed asset growth & -0.973 & 8.641 & 0.591 & 7.994 \\
Cash reserve & 0.000 & 0.513 & 0.099 & 0.114 \\
Sales volatility & $5,262.84$ & $5.72 \mathrm{E} 12$ & $2.370 \mathrm{E} 11$ & $6.01840 \mathrm{E} 11$ \\
Cash flow & -4.344 & 11.020 & 0.432 & 1.269 \\
Sales growth & -1.000 & 3.423 & 0.107 & 0.289 \\
\hline
\end{tabular}


Gadjah Mada International Journal of Business - Jan.-April, Vol. 21, No. 1, 2019

Table 3.Summary Statistics for NWC-to-Sales by Industry

\begin{tabular}{|c|c|c|c|c|c|c|c|}
\hline \multirow{2}{*}{ Industry } & \multicolumn{5}{|c|}{ Median } & \multirow{2}{*}{$\mathbf{N}$} & \multirow{2}{*}{ Slope } \\
\hline & 2010 & 2011 & 2012 & 2013 & 2014 & & \\
\hline Cement & 0.201 & 0.157 & 0.135 & 0.097 & 0.096 & 3 & -0.027 \\
\hline Ceramics, Glass, Porcelain & 0.245 & 0.238 & 0.189 & 0.192 & 0.191 & 6 & -0.015 \\
\hline Metal and Allied Products & 0.349 & 0.355 & 0.416 & 0.362 & 0.361 & 9 & 0.003 \\
\hline Chemicals & 0.308 & 0.263 & 0.236 & 0.260 & 0.298 & 6 & -0.002 \\
\hline Plastics and Packaging & 0.177 & 0.198 & 0.197 & 0.207 & 0.208 & 5 & 0.007 \\
\hline Animal Feed & 0.328 & 0.304 & 0.301 & 0.315 & 0.286 & 4 & -0.007 \\
\hline Wood Industries & 0.255 & 0.258 & 0.280 & 0.270 & 0.223 & 2 & -0.005 \\
\hline Pulp and Paper & 0.214 & 0.205 & 0.188 & 0.240 & 0.236 & 3 & 0.008 \\
\hline Automotive and Components & 0.230 & 0.160 & 0.179 & 0.212 & 0.210 & 9 & 0.001 \\
\hline Textile, Garment & 0.198 & 0.207 & 0.185 & 0.135 & 0.143 & 5 & -0.018 \\
\hline Footwear & 0.013 & -0.016 & 0.016 & -0.032 & 0.278 & 2 & 0.051 \\
\hline Cable & 0.145 & 0.073 & 0.150 & 0.370 & 0.340 & 5 & 0.069 \\
\hline Food and Beverages & 0.204 & 0.298 & 0.301 & 0.280 & 0.269 & 9 & 0.011 \\
\hline Tobacco Manufactures & 0.535 & 0.526 & 0.576 & 0.545 & 0.603 & 3 & 0.016 \\
\hline Pharmaceuticals & 0.371 & 0.366 & 0.338 & 0.334 & 0.347 & 8 & -0.008 \\
\hline Cosmetics and Household & 0.220 & 0.319 & 0.355 & 0.331 & 0.324 & 4 & 0.022 \\
\hline Houseware & 0.408 & 0.445 & 0.466 & 0.453 & 0.495 & 2 & 0.018 \\
\hline
\end{tabular}

the association with the evolution of median NWC-to-sales during the five-year period. It also shows that ten of the 17 industries had a positive time trend. This indicates that most manufacturing companies in Indonesia tend to increase their investment in working capital, as happens in US and European firms.

\section{Excess WCM and Firm Performance}

Table 4 presents the regression results of the relationship between excess NWC and stock performance. A variable that became the main concern was the excess NWC, measured by using the deviation of the firm's NWC from the industry median. Column 1 shows the results of the linear model, while column 2 shows the results of the asymmetric models.
Table 4 shows that excess NWC has a negative and significant effect on firm performance. This indicates that excess investments in working capital can have a negative effect on firm performance. First, a large working capital in its inventory will result in a large number of supply costs, such as warehouse rent, insurance and security expenses, which tend to increase along with the increase in inventory. Moreover, the increase in working capital needs more funding, involving capital costs and opportunity costs. Shin and Soenen (1998) suggest that a firm with too large a working capital can potentially encounter high financing expenses, which eventually will increase the credit risk. The greater the working capital, the greater the possibility that the firm will experience financial dis- 
Table 4. Excess Net Working Capital and Stock Return

\begin{tabular}{lcccc}
\hline \multirow{2}{*}{ Variable } & \multicolumn{2}{c}{$(1)$} & \multicolumn{2}{c}{$(2)$} \\
\cline { 2 - 5 } & Coefficient & $p$-value & Coefficient & $p$-value \\
\hline Excess $N W C_{t-1}$ & $-2.080 * *$ & 0.038 & & \\
Excess $N W C_{t-1} \times D$ & & & $-1.787 *$ & 0.075 \\
Excess $N W C_{t-1} \times(1-D)$ & & & 0.228 & 0.820 \\
Firm Size & -0.907 & 0.365 & 0.265 & 0.791 \\
Leverage & -1.362 & 0.174 & -0.713 & 0.476 \\
Age & -0.728 & 0.467 & -0.686 & 0.493 \\
Risk & -1.412 & 0.159 & -1.371 & 0.171 \\
Fixed assets growth & 0.140 & 0.889 & 0.463 & 0.644 \\
Cash reserves & $1.841 *$ & 0.066 & $2.746 * * *$ & 0.006 \\
Sales volatility & 0.624 & 0.533 & 0.556 & 0.579 \\
Cash flow & -1.161 & 0.246 & -1.192 & 0.234 \\
Sales Growth & $2.330 * *$ & 0.020 & $2.413 * *$ & 0.016 \\
Sargan test: $p$ - value & & 0.317 & & 0.287 \\
m2: p-value & & 0.345 & & 0.321 \\
Dependent Variable: Excess Return & & & \\
\hline
\end{tabular}

Note: Probability values (p-value) based on White robust standard errors for heteroskedasticity. ***; ***, * show statistical significances at 1 percent, 5 percent, and 10 percent levels, respectively. $\mathrm{m}$, is a serial correlation test of second-order using residuals of first differences, asymptotically distributed as $\mathrm{N}(0,1)$ under null hypothesis of no serial correlation. Sargan test is a test of overidentifying restrictions distributed asymptotically under null hypothesis of validity of instruments as chi-squared

tress and face a greater risk of bankruptcy. On the other hand, excess investment in working capital signifies that funds will be locked in the working capital, which will affect the firm's ability to execute opportunities for an unexpected profitable investment. The regression results in column 1 in Table 4 are confirmed by the results of a regression on the asymmetrical model in column 2, where the negative and significant relationship in column 1 was due to the fact that the majority of the sample companies experienced overinvestment (positive excess NWC). Column 2 shows that only in companies experiencing overinvestment or positive excess NWC [Excess $N W C \times \mathrm{x}$ ), is the reduction in excess NWC likely to have a positive effect on firm performance. Conditions in companies with excess working capital provide an incentive to reduce working capital levels and minimize financial risks, financial distress and bankruptcy cost (Banos-Caballero et al. 2014).

On the other hand, for companies that experience underinvestment or negative excess N W C [Excess NWC x (1-D)], an increase in any excess NWC has a positive influence on stock performance. This is due to the fact that additional working capital 
helps the firm to grow by increasing its sales and revenue. Greater supply holdings are believed to reduce supply costs, avoid the effects of price fluctuations, and minimize the loss of sales due to stock-outs. Extending credit to consumers, as argued by Summers and Wilson (2002), can also have a positive effect on sales because the implementation of price discrimination (the imposition of different prices) becomes a guarantee of product quality and maintains long-term relationships with consumers.

With regard to the control variables, cash reserves and sales growth have positive and significant effects on the excess return. The higher the cash reserve, the higher the performance of the firm, based on the transaction cost theory; holding more cash will reduce the transaction cost (Keynes 1934). When companies do not have enough cash to pay their bills they must borrow money from external parties, until the companies can change non-cash assets into cash, thus increasing the amount of interest expenses and transaction costs. The precautionary motive also explains that the cash reserves are used in preparation for future investment (Bates et al. 2009; Han and Qiu 2007; Almeida et al. 2004; Keynes 1934). When companies do not have cash or liquid assets in sufficient quantities, they will have difficulty in executing sudden, new, profitable investment opportunities. Sales growth has a positive and significant impact on firm performance. According to Opler and Titman (1994) sales growth could act as a proxy in evaluating company performance. Firms with high sales growth are said to have good performance; as the number of sales increases, the company's profit and cash flow also increase.

\section{Excess NWC and Risks}

Besides the stock return, risk is an alternative indicator to measure firm performance, due to the impact of the working capital's investment policy. Companies that have an aggressive working capital investment policy will potentially increase the liquidity risk of the firm, and also the risk of stock price fluctuations and loss of sales due to potential stock-outs. To obtain a more comprehensive analysis, as to whether the risk channel would be affected by working capital management, in this study the relationship between NWC and risk was also tested, as shown in Table 5. Column 1 shows the results of samples in general, while column 2 shows different possible effects in overinvestment and underinvestment companies (asymmetric model).

The results of the regression analysis in Table 5 show that excess NWC in column 1 has a significant and negative effect on the volatility of the stock. It indicates that the greater the working capital, the lower the firm risk. Furthermore, when considering the results of a regression on an asymmetric model (column 2), the negative effect (column 1) apparently was mostly contributed by a group of companies that experienced negative excess NWC (underinvestment). These results correspond with the results from Aktas et al. (2014). As in Table 4 column 2, the relation between excess NWC and firm risk was negative, both in overinvestment and underinvestment companies. However, the negative effect in overinvestment companies was insignificant. These results indicated that the group of companies that had implemented a conservative working capital policy from the beginning had a relatively low risk, so that additional working 
Table 5.Excess Net Working Capital and Risk

\begin{tabular}{|c|c|c|c|c|}
\hline \multirow{2}{*}{ Variables } & \multicolumn{2}{|c|}{ (1) } & \multicolumn{2}{|c|}{ (2) } \\
\hline & Coefficient & p-value & Coefficient & p-value \\
\hline Excess $N W C_{t-1}$ & $-1.756 *$ & 0.080 & & \\
\hline Excess $N W C_{t-1} x D$ & & & -0.159 & 0.874 \\
\hline Excess $N W C_{t-1} x(1-D)$ & & & $-1.654 \%$ & 0.099 \\
\hline Firm Size & $-4.106 * * *$ & 0.000 & $-2.702 * * *$ & 0.007 \\
\hline Leverage & $-2.815 \% \%$ & 0.005 & -0.816 & 0.415 \\
\hline Age & -1.277 & 0.202 & $-3.122 * * *$ & 0.002 \\
\hline Cash reserves & -1.418 & 0.157 & -1.261 & 0.208 \\
\hline Sales volatility & 0.204 & 0.838 & 0.051 & 0.959 \\
\hline Cash flow & 0.750 & 0.453 & 0.280 & 0.780 \\
\hline Sales Growth & 1.486 & 0.138 & 1.257 & 0.210 \\
\hline Sargan test: $p$-value & & 0.245 & & 0.203 \\
\hline $\mathrm{m}_{2}: \mathrm{p}$-value & & 0.323 & & 0.312 \\
\hline ependent Variable & & & & \\
\hline
\end{tabular}

Note: Probability values (p-value) based on White robust standard errors for heteroskedasticity. ***, **, * show statistical significances at 1 percent, 5 percent, and 10 percent levels, respectively. $m_{2}$ is a serial correlation test of second-order using residuals of first differences, asymptotically distributed as $\mathrm{N}(0,1)$ under null hypothesis of no serial correlation. Sargan test is a test of overidentifying restrictions distributed asymptotically under null hypothesis of validity of instruments as chi-squared.

capital in overinvestment companies was no longer significant in reducing the risk, that was relatively small. Different results were implied in the underinvestment firms, a group of underinvestment companies tends to have a higher and more varied risk, namely the risk of stock price fluctuations, the risk of stock-outs and a liquidity risk. Therefore, the addition of working capital in the firms will have a significant effect on reducing the level of firm risk in general, as measured by the standard deviation of the stock price. Concerning the control variables, firm size, leverage and age have a negative effect on risk. The sign of the coefficient is consistent with the literature (see e.g. Coles et al. 20 06)
In addition, we employ a Variance Inflation Factor (VIF) for each model to ensure that the potential multicollinearity problem does not exist in the analysis. The largest value of VIF is 1.380 , indicating that there is no multicollinearity problem in our models.

\section{Conclusion}

Working capital management is very important for the sustainability of a firm's operations, and also affects the firm's performance. This study aimed to investigate the influence of working capital investment policies on firm performance and risk in Indonesia. The samples used in this study 
were manufacturing companies listed on the Indonesian Stock Exchange (IDX) with the sample period being between 2005 and 2014. Firm performance was measured using the excess return, while risk was measured by the annualized standard deviation of the monthly stock return. The independent variable, namely working capital, was measured using the excess net working capital, which is the deviation between the net working capital-to-sales ratio of each firm against the median ratio of net working capital-to-sales in the corresponding industry/years. Furthermore, this study also intended to observe the potential of the asymmetric influence in companies experiencing overinvestment in working capital (positive excess NWC) and underinvestment (negative excess NWC), on firm performance.

Regression analysis on 425 firms/year observations was obtained as follows: Excess working capital had a negative and significant effect on firm performance. This suggests that the excess NWC will lead to lower firm performance. Interestingly, it was also observed that the effect was not symmetrical between excess working capital and performance in both over investment and underinvestment companies. In overinvestment companies, additional working capital actually caused a negative effect on performance. On the contrary, in underinvestment companies, additional working capital had a positive effect on firm performance. Moreover, analysis of the effect of the working capital's investment policy on the risks in general revealed that excess working capital had a negative and significant effect on the firms' risks. This indicates that greater investment in working capital will reduce firm risk. In addition, it was also noted that the relationship between positive and negative excess working capital on risk was not symmetric, where the additional working capital in an overinvestment condition could not lower the risk significantly. This condition was due to the fact that overinvestment companies, from the beginning, have had a lower risk. Meanwhile, in under-investment companies, the additional working capital had a significant effect in reducing the firms' risks.

These findings have important implications to both academics and managers, especially in Indonesia. Firstly, given the evidence of the asymetric effect of working capital on return and risk, any results from previous or future studies that do not consider nonlinearity, may lead to inappropriate conclusions. Secondly, management should seriously consider working capital's utilization, for it has a significant effect on firm performance and risk. Most managers focused on the long-term investments and their financing, but simply overlooked the working capital as a part of their daily operational decisions. Achieving the optimal working capital will result in maximized firm performance and a minimal level of risk. Thirdly, as the nature of a company is to minimize risk, it should avoid investing too much in working capital. Some companies might preserve an excess of working capital, to avoid terminating their operational activities, but this will eventually reduce firm performance, without substantially reducing the risks. Hence it will result in the companies' declining values and ultimately incur the displeasure of their shareholders. 


\section{References}

Abuzayed, B. 2012. Working Capital Management and Firms' Performance in Emerging Markets: The Case of Jordan. International Journal of Managerial Finance 8(2): 155-179.

Aktas, N., E. Croci, and D. Petmezas. 2015. Is working capital management value-enhancing? Evidence from firm performance and investments. Journal of Corporate Finance 30: 98-113.

Almeida, H., M. Campello, and M. Weisbach. 2004. The cash flow sensitivity of cash. Journal of Finance 59 (4): 1777-1804.

Almeida, J. R., and W. Eid Jr. 2014. Access to finance, working capital management and company value: Evidences from Brazilian companies listed on BM\&FBOVESPA. Journal of Business Research 67: 924-934.

Arellano, M., and S. Bond. 1991. Some test of specification for panel data: Monte Carlo evidence and an application to employment equations. Reviere of Economic Studies 58: 277-297.

Baños-Caballero, S., P. García-Teruel, and P. Martínez-Solano. 2012. How does working capital management affect the profitability of Spanish SME's? Small Business Economics 39: 517529.

Banos-Caballero, S., P. J. Garcia-Teruel, and P. Martinez-Solano. 2014. Working capital management, corporate performance, and financial constraints. Journal of Business Research 67: 332338.

Barber, B. M., and J. D. Lyon. 1997. Detecting long-run abnormal stock returns: the empirical power and specification of test statistics. Journal of Finance Economics 43: 341-372.

Bates, T. W., K. Kahle, and R. Stulz. 2009. Why Do U.S. firms hold so much more cash than they used to? Journal of Finance 64: 1985-2021.

Blinder, A. S., and L. J. Maccini. The resurgence of inventory research: What have we learned? Journal of Economic Surveys 5: 291-328.

Buchmann, P., A. Roos, U. Jung, and A. Martin. 2008. Cash for Growth: the Neglected Power of Working-Capital Management. The Boston Consulting Group.

Charitou, M., L. Petros, B. S. Halim. 2012. The relationship between working capital management and firm's profitability: An empirical investigation for an emerging Asian country. International Business and Economics Research Journal 11 (8): 839 - 848.

Chittenden, F., P. Poutziouris, and N. Michaelas. 1998. Financial Management and Working Capital Practices in UK SMEs. Manchester: Manchester Business School.

Coles, J. L., N. D. Daniel, and L. Naveen. 2006. Managerial incentives and risk taking. Journal of Financial Economics 79: 431-468

Corsten, D., and T. Gruen. 2004. Stock-outs cause walkouts. Harvard Business Reviere 82: 26-28.

Denis, D. J., and V. Sibilkov. 2010. Financial constraints, investment, and the value of cash holdings. Review Finance Study 23: 247-269.

Deloof, M. 2003. Does working capital management affect profitability of Belgian firms? Journal Business Finance and Accounting 30: 573-587.

Deloof, M., and M. Jegers. 1996. Trade credit, product quality, and intragroup trade: Some European evidence. Financial Management 25: 33-43. 
Gadjah Mada International Journal of Business - Jan.April, Vol. 21, No. 1, 2019

Duchin, R., O. Ozbas, and B. A. Sensoy. 2010. Costly external finance, corporate investment, and the subprime mortgage credit crisis. Journal of Financial Economics 97: 418-435.

Dunn, P., and L. Cheatham. 1993. Fundamentals of small business financial management for startup, survival, growth, and changing economic circumstances. Managerial Finance 19: 1-13

Emery, G. W. 1984. A pure financial explanation for trade credit. Journal of Financial and Quantitative Analysis 19: 271-285.

Emery, G. W. 1987. An optimal financial response to variable demand. Journal of Financial and Quantitative Analysis 22: 209-225.

Ernst, and Young. 2015. All Tied Up: Working Capital Management Report.

Faden, C. 2014. Optimizing firm Performance: Alignment of Operational Success Drivers on the Basis of Empirical Data. Springer Science and Business Media. http://www.springer.com/ 978-3-658-02745-2.

Fama, E. F., and K. R. French. 1993. Common risk factors in the returns on stocks and bonds. Journal of Financial Economics 33: 3-56.

Faulkender, M., and R. Wang. 2006. Corporate financial policy and the value of cash. The Journal of Finance 61 (4): 1957-1990.

Fazzari, S. M., and B. C. Petersen. 1993. Working capital and fixed investment: new evidence on financing constraints. RAND J. Econ. 24 (3): 328-342.

Fess, P. 1966. The working capital concept. The Accounting Review: 266-270.

García-Teruel, P., and P. Martínez-Solano. 2007. Effects of working capital management on SME profitability. International Journal of Managerial Finance 3: 164-177

Hawawini, G., C. Viallet, and A. Vora. 1986. Industry influences on corporate working capital decisions. Sloan Management Review 27 (4) (Summer): 15-24.

Han, S., and J. Qiu, 2007. Corporate precautionary cash savings. Journal of Corporate Finance 13: 43-57.

Hill, M. D., G. W. Kelly, and M. J. Highfield. 2010. Net operating working capital behavior: A first look. Financial Management 39: 783-805.

Keynes, J. M. 1934. The Applied Theory of Money 2. Mcmillan and Co.

Kieschnick, R., M. LaPlante, and R. Moussawi. 2013. Working capital management and shareholder wealth. Review Finance 17: 1827-1852.

Kim, Y. H., and K. H. Chung. 1990. An integrated evaluation of investment in inventory and credit: A cash flow approach. Journal of Business Finance and Accounting 17: 381-390.

Lee, Y. W., and J. D. Stowe. 1993. Product risk, asymmetric information, and trade credit. Journal of Financial and Quantitative Analysis 28: 285-300.

Lind, L., M. Pirttila, S. Viskari, F. Schupp, and T. Karri. 2012. Working capital management in the automotive industry: Financial value analysis. Journal of Purchasing and Supply Management 18: 92-100.

Mohamad, N. E. A. B., and N. B. M. Saad. 2010. Working capital management: The effect of market valuation and profitability in Malaysia. International Journal of Business and Management 5 (11): 140-147. 
Moussa, A. A. 2018. The impact of working capital management on firms' performance and value: Evidence from Egypt. Journal of Asset Management 19 (4): 259-273.

Ng, C. K., J. K. Smith, and R. L. Smith. 1999. Evidence on the determinants of credit terms used in interfirm trade. Journal of Finance 54: 1109-1129.

Ogundipe, S. E., A. Idowu, and L.O. Ogundipe. 2012. Working capital management, firms' performance and market valuation in Nigeria. International Journal of Social, Behavioral, Educational, Economic, Business and Industrial Engineering 6 (1): 124-128.

Opler, T. C. and S. Titman .1994. Financial distress and corporate performance. Journal of Finance 49: 1015-1040.

Petersen, M., and R. Rajan. 1997. Trade credit: Theories and evidence. Review of Financial Studies 10: 661-691.

Rozari, P. E., Y. S. Sudarma, R. Indiastuti, and E. Febrian. 2015. The integrated measuring of working capital management efficiency on financial performance in Indonesia Stock Exchange. Information Management and Business Review 7 (3): 26-33.

Shin, H., and L. Soenen. 1998. Efficiency of working capital management and corporate profitability. Financial Practice Education 8: 37-45.

Shulman, J. M., and R. A. Cox. 1985. An integrative approach to working capital management. Journal of Cash Management 5 (6): 64-68.

Smith, K. 1980. Profitability versus Liquidity Tradeoffs in Working Capital Management, in Readings on the Management of Working Capital. St. Paul, New York: West Publishing Company.

Summers, B., and N. Wilson. 2002. Trade credit terms offered by small firms: Survey evidence and empirical analysis. Journal of Business Finance and Accounting 29: 317-335.

Vural, G., A. G. So“kmen, and E. H. C. Etenak. 2012. Affects of working capital management on firm's performance: Evidence from Turkey. International Journal of Economics and Financial Issues 2 (4): 488-495.

Wang, W. 2002. Liquidity management, operating performance and corporate value: evidence from Japan and Taiwan. Journal of Multinational Financial Management 12: 159-169.

Wasiuzzaman, S. 2015. Working capital and firm value in an emerging market. International Journal of Managerial Finance 11 (1): 60-79

Wilner, B. S. 2000. The exploitation of relationship in financial distress: The case of trade credit. Journal of Finance 55: 153-178. 